\title{
Cisplatin-associated Anemia: An Erythropoietin Deficiency Syndrome
}

Patricia A. Wood and William J. M. Hrushesky

Stratton Veterans Affairs Medical Center and Albany Medical College, Albany, New York 12208

\begin{abstract}
Cisplatin-based therapy results in a cumulative anemia that is disproportionate to the effects on other blood cells. The severity of this treatment-induced anemia and the resultant transfusion requirement in cancer patients correlate with cisplatin-induced renal tubular dysfunction. Observed/expected serum erythropoietin (EPO) ratios decline with progressive cisplatin therapy and are proportionate to the degree of renal dysfunction. Recovery from anemia and of observed/expected serum EPO ratios in patients occurs after cessation of cisplatin therapy, along with restoration of renal tubular function. Creatinine clearance, however, remains permanently depressed. Cisplatin-treated rats develop progressive renal dysfunction and anemia that persists for many weeks, without effects on white blood cell counts. The anemia is also associated with a lack of expected EPO and reticulocyte response. With EPO administration, cisplatin-treated rats exhibit a greater reticulocyte response and hematocrit increment then non-cisplatin-treated rats given EPO, indicating minimal erythroid precursor cell damage from cisplatin. These results indicate the primary etiology of cisplatin-associated anemia is a transient, but persisting EPO deficiency state resulting from cisplatin-induced renal tubular damage, which can be prevented or treated by hormone (EPO) replacement. (J. Clin. Invest. 1995. 95:1650-1659.) Key words: cisplatin • anemia • erythropoietin • cancer $\cdot$ kidney
\end{abstract}

\section{Introduction}

The major source of erythropoietin (EPO) ${ }^{1}$ in the adult is the kidney, with evidence for production by peritubular interstitial cells $(1,2)$ although some studies argue for a renal tubular cell origin (3). The anemia of chronic and acute renal failure is largely the result of an EPO deficiency due to decreased EPO production from the diseased kidney $(4,5)$. Administration of EPO promptly corrects the anemia associated with renal failure in the majority of patients $(6,7)$.

Cisplatin is a widely used metal-based anticancer drug that causes early and progressive renal tubular dysfunction and subsequent glomerular drop out. Chronic administration of cisplatin

Address correspondence to William J. M. Hrushesky, M.D., Stratton VA Medical Center (111C), 113 Holland Ave., Albany, NY 12208. Phone: 518-462-3311, ext. 2792; FAX: 518-462-0626.

Received for publication 23 August 1994 and in revised form 11 November 1994.

1. Abbreviations used in this paper: $\mathrm{APH}$, acetylphenyl hydrazine; $\mathrm{CrCl}$, creatinine clearance; EPO, erythropoietin; $\mathrm{O} / \mathrm{E}$, observed/expected; $\mathrm{P}_{50}$, partial pressure of oxygen when hemoglobin is $50 \%$ saturated.

The Journal of Clinical Investigation, Inc.

Volume 95, April 1995, 1650-1659 in animals $(8-10)$ and in cancer patients $(11,12)$ has been reported to cause progressive anemia at moderate levels of azotemia that appears disproportionate to the effects on white blood cells. The occurrence of a predominant deficiency in erythrocyte production along with renal toxicity suggests that this drugassociated anemia might result in part from deficient renal production of EPO due to cisplatin-induced renal toxicity. The often complex nature of anemia in cancer patients, frequent administration of myelotoxic drugs along with cisplatin, frequent use of red cell transfusions, infrequency with which anemia is reported, and incomplete characterization of anemia in clinical cancer trials have prompted us to look at this issue more carefully.

We have studied a homogeneous and well-defined group of cancer patients receiving prolonged cisplatin-based therapy. This study attempts to describe carefully the hematologic characteristics and degree of cisplatin-associated anemia and contrasts it with other associated cytopenias. Cisplatin-associated anemia is correlated with markers of tubular and overall renal damage. Finally, this study evaluates the resulting serum EPO response to the anemia. Because this group of patients received a general marrow toxin (doxorubicin) as well as cisplatin, we also studied purely cisplatin-induced renal toxicity and anemia in rats. These studies define the endogenous EPO response to pure cisplatin-induced anemia and the response of this anemia to recombinant human EPO.

\section{Methods}

\section{Clinical studies}

Patients. All patients signed informed consent for study participation. The study protocol was approved by the Institutional Review Board. 54 patients were initially enrolled. Seven of these patients were subsequently excluded from study (see exclusion criteria). The 47 remaining patients are the basis of this report. These 47 patients had either ovarian $(n=28)$ or bladder $(n=19)$ cancer and were studied over a span of $7 \mathrm{yr}$ in the Clinical Research Center at the University of Minnesota. These patients had advanced stage ovarian or bladder tumors as follows: ovarian cancer: 1 stage IC with peritoneal spill, 18 stage III, 9 stage IV patients; bladder cancer: 3 stage $C, 5$ stage $D_{1}, 11$ stage $D_{2}$ patients. The median age was $60.0 \pm 1.5 \mathrm{yr}$ (range $45-88 \mathrm{yr}$ ) with a male/female ratio of $1: 2.9 .87 \%$ of patients had surgical resection of their ovarian disease or primary bladder cancer on average $42 \mathrm{~d}$ before study entry. Three patients had received prior radiation therapy $(1 \mathrm{mo}, 16 \mathrm{mo}$, and $12 \mathrm{yr}$ before study), two had received prior non-cisplatin chemotherapy (oral melphalan and tamoxifen, intravenous cyclophosphamide), and one patient had received both prior radiation therapy ( $2 \mathrm{yr}$ before study) and local chemotherapy (intravesicular thiotepa).

Chemotherapy protocol. Each course of therapy consisted of intravenous bolus doxorubicin $\left(60 \mathrm{mg} / \mathrm{m}^{2}\right)$ followed $12 \mathrm{~h}$ later by intravenous cisplatin $\left(60 \mathrm{mg} / \mathrm{m}^{2}\right)$, with a vigorous normal saline and mannitol hydration protocol. Courses were repeated every $28 \mathrm{~d}$ for a total of nine planned treatments. Patients were taken off study for severe toxicity (clinical congestive heart failure, creatinine clearance $[\mathrm{CrCl}]<30$ ) or tumor progression.

Tumor response assessment. Tumor status was evaluated upon entering the study (by physical exam each month and by computerized tomography and chest radiographs on entry), after five courses, and 
upon termination of treatment. Responses were graded as complete, partial, or unresponsive disease by standard criteria.

Toxicity assessment. Patients were studied upon protocol entry and $28 \mathrm{~d}$ after each course of chemotherapy. Routine serum chemistries and serum magnesium were measured. Full 24-h urine collections for $\mathrm{CrCl}$ were measured and expressed as $\mathrm{cm}^{3} / \mathrm{min} / 1.73 \mathrm{~m}^{2}$.

Anemia assessment. Before study entry and after each treatment course, white blood counts with differentials, platelet counts, red cell numbers, hematocrit, hemoglobin, and red cell indices were performed by automated cell counter. Reticulocyte concentrations were determined by new methylene blue staining and expressed as corrected reticulocytes by correction for the observed hematocrit divided by a normal hematocrit of $45 \%$. Other causes for possible anemia were aggressively sought upon entry and throughout treatment. Initial and serial serum iron, total iron binding capacity, ferritin, serum $B_{12}$, red cell folate, direct Coomb's tests, and stool guaiac tests were measured. Bone marrow biopsies and aspirates were obtained before the first course and/or after more than five courses of treatment. Routine morphology, cellularity, differentials, assessment of tumor involvement, and iron stains were each evaluated on 31 bone marrow specimens form a subset of 20 patients. Total red cell mass and red cell half-life were measured in a subset of patients by ${ }^{51} \mathrm{Cr}$ labeling. Whole blood $\mathrm{P}_{50}$ values (oxygen tension at which hemoglobin is half-saturated by cooxymetry) were determined in a subset of five patients. Serum EPO levels were measured by commercial assays using a solid-phase enzyme immunoassay with a mAb to recombinant human EPO (JCL Clinical Research Corp., Knoxville, TN). The normal range for EPO values was $7-38 \mathrm{mU} / \mathrm{ml}$. Using the $\log$ relationship between serum EPO and hematocrit from large groups with normal hematocrits and subjects with uncomplicated anemia, an expected log EPO value was calculated for each patient's concurrent hematocrit. The following formula was used: $\log \mathrm{EPO}=-0.098$ (hematocrit) +5.57 . The appropriateness of the EPO response was estimated by calculating the ratio of the observed/expected $(\mathrm{O} / \mathrm{E})$ serum EPO values multiplied by 100 for each hematocrit. Red cell transfusions were routinely given just before a monthly chemotherapy cycle, when the hematocrit fell to $<26-28 \%$. The cumulative number of red cell transfusions was recorded for each patient throughout therapy.

Exclusion criteria. Seven patients were excluded from the study for the following reasons to eliminate well-documented additional causes for anemia or alteration in EPO levels due to reasons other than malignancy: iron deficiency $(n=3)$ and significant inflammatory or metastatic hepatic disease $(n=3)(>30 \%$ tumor involvement or liver enzymes and baseline ferritin levels two to three times normal). Hepatic disease itself has been reported to alter EPO production (13). One patient was excluded for completion of less than four courses secondary to early tumor progression.

\section{Rat studies}

Cisplatin treatment. Procedures for animals followed approved National Institutes of Health guidelines with local Institutional Animal Care Committee review. Female Fischer 344 rats given repeated cisplatin were studied as a model of cisplatin renal damage and anemia, which parallels the renal damage seen with chronic cisplatin administration in humans $(14,15)$. Two separate studies were conducted using 20 rats $(n=10$ per treatment group), at age $15 \mathrm{wk}$ in study $I$, and 32 rats $(n=16$ per treatment group), at age $9 \mathrm{wk}$ in study II. Equal numbers of rats were treated twice weekly with $2 \mathrm{mg} / \mathrm{kg}$ cisplatin dissolved in mannitolcontaining saline (Bristol Meyers, Princeton, $\mathrm{NJ}$ ) or saline alone by the intraperitoneal route. Rats received a total of eight injections of cisplatin or saline over $25 \mathrm{~d}$.

EPO treatment. After completing drug treatment, rats were observed for either $32 \mathrm{~d}$ (study I) or $6 \mathrm{~d}$ ( study II). Half of each cisplatin-treated and saline-treated rats received either twice weekly subcutaneous saline or $300 \mathrm{U} / \mathrm{kg}$ recombinant human $\mathrm{EPO}(4,000 \mathrm{U} / \mathrm{ml} 0.25 \%$ human serum albumin; study I, Amgen, Thousand Oaks, CA; study II, lot N-5088, Ortho Biotech, Raritan, NJ) for a total of four doses.

Toxicity and response measurements. Heparinized peripheral blood samples $(200 \mu \mathrm{l})$ were collected once weekly by serial tail vein cannulation (study I) or small tail cuts (study II) for hematocrit determination and reticulocyte concentrations by new methylene blue staining. Plasma from these samples was recovered for creatinine and EPO measurements. Plasma creatinine was determined by the colorimetric Jaffe rate method (Creatinine Analyzer 2, Beckman Instrs., Inc., Fullerton, CA). Endogenous rat EPO levels were measured by solid-phase enzyme immunoassay using a mAb (22F7-1) against recombinant human EPO (JCL Clinical Research Corp.) Additional control animals were treated with intraperitoneal acetylphenyl hydrazine (APH; $28 \mathrm{mg} / \mathrm{kg}$ for $4 \mathrm{~d}$; Sigma Chemical Co., St. Louis, MO) to induce hemolysis with a proliferative anemia to generate plasma samples with elevated EPO levels. At the termination of the study, animals were exsanguinated by cardiac puncture and central blood counts were analyzed by automated blood cell counter.

\section{Data analysis}

ANOVA ( $F$ and $P$ values) were used to determine the sources of variance from the mean of continuous variables such as hemoglobin or 24$\mathrm{h} \mathrm{CrCl}$. When the data were inspected for a single variable (e.g., course number), a one-way ANOVA was used. When several competing sources of variance were contrasted concurrently (e.g., course number, tumor response, tumor burden, and smoking status), multiple-way ANOVA were used to determine the effects of chemotherapy or no treatment (study entry), or course number. Proportionalities were compared by chi-square analysis (chi-square and $P$ values). Correlations were assessed by linear regression of individual values to establish the significance, correlation coefficient $(r)$, and the rate of change of variables with respect to one another. Values listed are individual values or the mean $\pm S E$ for grouped data. Results are considered statistically significant if $P<0.05$.

\section{Results}

\section{Clinical studies}

Hematologic toxicity. Before therapy, these 47 cancer patients exhibited, on average, a mild anemia with hemoglobin values of $12.3 \pm 0.2 \mathrm{~g} / \mathrm{dl}$ (range $9.7-14.9 \mathrm{~g} / \mathrm{dl}$ ) and hematocrits of $36.7 \pm 0.5 \%$ (range $28.2-44.6 \%$ ). 11 of these patients with advanced cancer had hemoglobin values within the normal range. All 47 patients completed a total of 365 monthly courses of chemotherapy, which serve as the data base for this report. These patients completed a mean of $7.9 \pm 0.2$ courses of therapy and were given a mean of $473.6 \pm 12.5 \mathrm{mg} / \mathrm{m}^{2}$ cisplatin and $461.5 \pm 13.0 \mathrm{mg} / \mathrm{m}^{2}$ doxorubicin. A progressive and cumulative anemia was observed with successive courses of cisplatin/doxorubicin chemotherapy (Table I). The onset of this hemoglobin decline was not delayed but was seen after the first course of therapy, with continued progression with further therapy. An average hemoglobin decline of $0.22 \mathrm{~g} / \mathrm{dl}$ per course was observed when considering only values before the first red cell transfusion $(n=253, r=0.38, P<0.001)$. This rate of hemoglobin decline underestimates the true rate of hemoglobin decline because of the necessity to administer red cell transfusions. Without red cell transfusion, the true rate of hemoglobin decline would obviously be much steeper. The lowest hemoglobin value recorded $4 \mathrm{wk}$ after therapy was $5.9 \mathrm{~g} / \mathrm{dl}$. In contrast to this progressive anemia, total white blood cell and platelet counts showed only a slight decline within the normal range. Additionally, the greatest decline in blood leukocytes occurred after the first few courses and was much less prominent later in therapy.

\section{Characteristics of treatment-induced anemia}

Reticulocyte response and transfusions. Before red cell transfusions, corrected reticulocytes failed to rise with successive chemotherapy courses despite progressive anemia (Table I). This 
Table I. Blood Counts, Reticulocytes, and Red Cell Transfusions in Patients before Each Course of Cisplatin/Doxorubicin Chemotherapy

\begin{tabular}{|c|c|c|c|c|c|c|c|c|c|c|}
\hline & \multicolumn{10}{|c|}{ Chemotherapy course } \\
\hline & 1 & 2 & 3 & 4 & 5 & 6 & 7 & 8 & 9 & 10 \\
\hline Hemoglobin* (g/dl) & $\begin{array}{c}12.3 \\
(0.20)\end{array}$ & $\begin{array}{l}11.8 \\
(0.2)\end{array}$ & $\begin{array}{l}11.3 \\
(0.2)\end{array}$ & $\begin{array}{l}10.9 \\
(0.2)\end{array}$ & $\begin{array}{l}10.7 \\
(0.2)\end{array}$ & $\begin{array}{l}11.3 \\
(0.3)\end{array}$ & $\begin{array}{l}11.1 \\
(0.2)\end{array}$ & $\begin{array}{l}10.7 \\
(0.4)\end{array}$ & $\begin{array}{l}10.1 \\
(0.4)\end{array}$ & $\begin{array}{l}10.8 \\
(0.5)\end{array}$ \\
\hline Corrected reticulocytes* $(\%)$ & $\begin{array}{c}1.6 \\
(0.1)\end{array}$ & $\begin{array}{c}1.9 \\
(0.2)\end{array}$ & $\begin{array}{c}1.9 \\
(0.2)\end{array}$ & $\begin{array}{c}1.7 \\
(0.2)\end{array}$ & $\begin{array}{c}2.1 \\
(0.3)\end{array}$ & $\begin{array}{c}2.2 \\
(0.2)\end{array}$ & $\begin{array}{c}2.2 \\
(0.2)\end{array}$ & $\begin{array}{c}2.3 \\
(0.4)\end{array}$ & $\begin{array}{c}2.2 \\
(0.4)\end{array}$ & $\begin{array}{c}1.6 \\
(0.4)\end{array}$ \\
\hline Cumulative units of RBC & $\begin{array}{c}0.2 \\
(0.1)\end{array}$ & $\begin{array}{c}0.4 \\
(0.2)\end{array}$ & $\begin{array}{c}0.8 \\
(0.3)\end{array}$ & $\begin{array}{c}1.6 \\
(0.4)\end{array}$ & $\begin{array}{c}2.5 \\
(0.5)\end{array}$ & $\begin{array}{c}3.9 \\
(0.6)\end{array}$ & $\begin{array}{c}5.0 \\
(0.7)\end{array}$ & $\begin{array}{c}5.9 \\
(0.8)\end{array}$ & $\begin{array}{c}6.9 \\
(1.1)\end{array}$ & $\begin{array}{c}8.4 \\
(1.4)\end{array}$ \\
\hline White blood cells $\left(\times 10^{-9} /\right.$ liter $)$ & $\begin{array}{c}7.0 \\
(0.5)\end{array}$ & $\begin{array}{c}6.0 \\
(0.3)\end{array}$ & $\begin{array}{c}5.4 \\
(0.2)\end{array}$ & $\begin{array}{c}5.0 \\
(0.2)\end{array}$ & $\begin{array}{c}4.9 \\
(0.2)\end{array}$ & $\begin{array}{c}4.7 \\
(0.3)\end{array}$ & $\begin{array}{c}4.5 \\
(0.2)\end{array}$ & $\begin{array}{c}5.0 \\
(0.3)\end{array}$ & $\begin{array}{c}4.5 \\
(0.2)\end{array}$ & $\begin{array}{c}4.7 \\
(0.3)\end{array}$ \\
\hline Platelets $\left(\times 10^{-9} /\right.$ liter $)$ & $\begin{array}{l}342 \\
(20)\end{array}$ & $\begin{array}{l}311 \\
(18)\end{array}$ & $\begin{array}{l}267 \\
(18)\end{array}$ & $\begin{array}{l}258 \\
(15)\end{array}$ & $\begin{array}{c}232 \\
(13)\end{array}$ & $\begin{array}{l}219 \\
(14)\end{array}$ & $\begin{array}{l}212 \\
(13)\end{array}$ & $\begin{array}{l}189 \\
(11)\end{array}$ & $\begin{array}{l}192 \\
(14)\end{array}$ & $\begin{array}{l}179 \\
(13)\end{array}$ \\
\hline
\end{tabular}

Values are given as mean (SEM). * Only values up until the first red cell transfusion are tabulated for hemoglobin and reticulocytes to avoid effects of red blood cell $(R B C)$ transfusion on these parameters. Reticulocytes are corrected by concurrent hematocrit.

therapy-induced anemia resulted in red cell transfusion in $\mathbf{4 0}$ $(85 \%)$ patients during treatment. There were $6.9 \pm 1.1$ units of packed red cells (range 2-20 units) administered per transfused patient. Treatment course number 4 was the median course for the first red cell transfusion, at which time $235 \mathrm{mg} / \mathrm{m}^{2}$ cisplatin had been given.

Hemolysis and bleeding. All direct Coomb's tests done at entry, after five courses, and after the final course were negative. No clinical episodes of overt bleeding occurred in any of these 47 patients. Serial stool guaiac tests throughout therapy remained negative.

Nutritional studies. Initial values and those measured upon study completion for serum $B_{12}(496 \pm 87$ vs $525 \pm 53 \mathrm{pg} / \mathrm{ml}$, respectively) and red cell folate (337 \pm 19 vs $471 \pm 29 \mathrm{ng} / \mathrm{ml})$ did not differ and remained within the normal limit. Despite the lack of a reticulocytosis, $B_{12}$, or folate deficiency, therapyinduced anemia was associated with a progressive increase within the normal range of mean red cell volume $(86.6 \pm 0.8$ to $95.2 \pm 0.6 \mathrm{fl}, P<0.001)$ and mean cell hemoglobin concentration $(33.7 \pm 0.1$ to $34.2 \pm 0.1 \mathrm{~g} / \mathrm{dl}, P=0.004)$ tabulated before intervention with any red cell transfusions. The red cell distribution width of erythrocyte size before any transfusion remained unchanged during treatment $(15.0 \pm 0.4$ vs $16.3 \pm 0.3, P=\mathrm{NS})$.

Iron studies. Serum iron $(58 \pm 3.9$ to $105.6 \pm 5.7 \mu \mathrm{g} / \mathrm{dl}, P$ $<0.001)$ and percent saturation $(23.6 \pm 1.7$ to $38.8 \pm 2.4 \%, P$ $<0.001$ ) both increased progressively within the normal range by the end of treatment. Total iron binding capacity remained unchanged ( $263 \pm 11$ vs $276 \pm 8 \mu \mathrm{g} / \mathrm{dl}, P=\mathrm{NS})$. In the absence of any significant hepatic disease or toxicity, serum ferritin levels increased markedly and progressively with therapy (initial $239 \pm 43$, after two to five courses $472 \pm 81$, after six to nine courses $731 \pm 84 \mathrm{ng} / \mathrm{ml}, P<0.001)$. Ferritin levels correlated well with the total number of red cell transfusions received ( $n$ $=132, r=0.75, P<0.001)$.

Oxygen affinity. Hemoglobin oxygen affinity was measured in whole blood samples in a small group of patients during treatment $(n=5)$ with a range of renal dysfunction $\mathrm{CrCl} \mathrm{64-}$ $123\left(\mathrm{~cm}^{3} / \mathrm{min}\right.$ per $\left.1.7 \mathrm{~m}^{2}\right)$ and hematocrit values $(23-33 \%)$. The $\mathbf{P}_{50}$ did not differ between these patients during treatment and normal volunteers $\left(P_{50}\right.$ : patients $27.1 \pm 2.1 \mathrm{mmHg}$ vs normal $26.8 \pm 0.6 \mathrm{mmHg}$ ).

Tagged red cell studies. ${ }^{51} \mathrm{Cr}$-tagged red cell studies were performed in five patients after treatment. These studies confirm the presence of anemia with a decreased in total red cell mass to $18.7 \pm 1.5 \mathrm{~cm}^{3} / \mathrm{kg}$ (normal $22-32 \mathrm{~cm}^{3} / \mathrm{kg}$ ) after more than two courses of treatment. The red cell mass in these patients correlated inversely with the degree of renal toxicity measured by concurrent 24 -h $\mathrm{CrCl}(r=0.89, P=0.046)$. Red cell halflife was measured in four of these same five patients after more than two courses of therapy. Three of these patients had not received red cell transfusions. One patient had received several red cell transfusions and was studied $1 \mathrm{mo}$ after the last transfusion. Red cell half-life values, measured 1 mo after chemotherapy, were diminished by nearly $40 \%$ in all four of these patients to $16.5 \pm 0.6 \mathrm{~d}$ (normal 25-30 d), which correlated with, but did not approach significance, the degree of anemia ( $r=0.93$, $p=0.068$ ). The measured red cell half-life in the one transfused patient did not differ markedly from the values in the nontransfused patients.

Bone marrow studies. Bone marrow biopsies before therapy $(n=8)$ were normocellular, with a qualitative decrease in sideroblasts and increased iron stores consistent with the anemia of malignancy. One patient had tumor cells detected in the marrow before therapy. After more than four courses of therapy, bone marrow $(n=23)$ cellularity was mildly decreased. The myeloid/erythroid ratio remained unchanged in the lower range of 3-4:1. The number of sideroblasts increased to the normal range, and iron stores further increased.

Serum EPO response during cisplatin-based chemotherapy Before therapy, on average, these patients with advanced cancer had a mild anemia (hematocrit $36.7 \pm 0.5 \%$, range $28.2-44.6 \%$ ) without apparent cause other than cancer. In response to this mild anemia, the average serum EPO concentration was $41.1 \pm 5.6 \mathrm{mU} / \mathrm{ml}$ (normal range $7-38 \mathrm{mU} / \mathrm{ml}$ ). There was no significant correlation between the log EPO values and concurrent hematocrit (Fig. $1 ; r=0.21, P=\mathrm{NS}$ ) in these patients before therapy. However, some of these EPO values, when considered in the context of the associated hematocrit, are low. Calculated O/E EPO values for these 47 individuals, on average, were $80.1 \pm 5.1 \%$ of the predicted value (range $37-156 \%$ ) for the concurrent hematocrit using a standard expected log EPO and hematocrit relationship. $38 \%$ of these cancer patients, though, still had an O/E EPO value near the expected or normal response $(\mathrm{O} / \mathrm{E}>90 \%)$ (Fig. 1; Table II). 


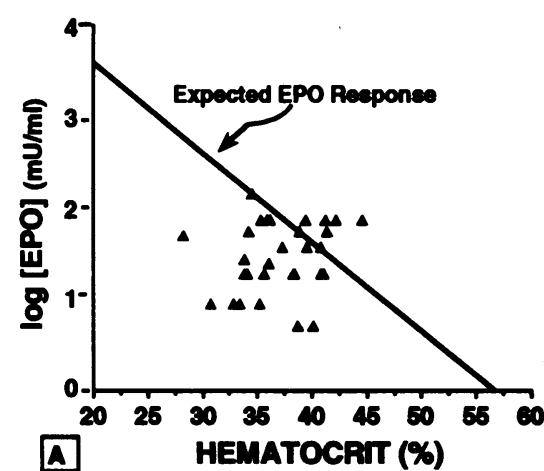

After four to nine courses of chemotherapy, but before any red cell transfusion, average EPO levels remained unchanged at $37.9 \pm 4.8 \mathrm{mU} / \mathrm{ml}$, even though the hematocrit had fallen markedly. Linear regression of these log EPO values against concurrent hematocrit during treatment showed no significant correlation ( $n=157, r=0.09, P=\mathrm{NS}$ ) (Fig. 1). During therapy, the calculated O/E EPO values declined further from pretreatment values despite declining hematocrits. After chemotherapy, the average calculated O/E EPO value declined to $60.1 \pm 2.8 \%$ of the predicted value (range $27-101 \%$ ). The proportion of patients with calculated $\mathrm{O} / \mathrm{E}$ values near the predicted response $(\mathrm{O} / \mathrm{E}>90 \%)$ declined to $3.2 \%$ compared with $38 \%$ before treatment. The decline in calculated $\mathrm{O} / \mathrm{E}$ EPO values was progressive with each chemotherapy course, with a significant correlation between course number and individual O/E EPO ratios for values up until the time of first transfusion $(n=189$, $r=0.254, p=0.004$ ) (Table II). The rate of fall of O/E EPO values before transfusion may underestimate the magnitude of deficiency in EPO response, since patient values are excluded after intervention with red cell transfusions. Correlation of all O/E EPO values (before and after red cell transfusions) with course number was also significant $(n=293, r=0.268, P$ $<0.0001$ ) (data not shown).

\section{Cisplatin-induced renal toxicity}

Before therapy, these patients with advanced cancer had nearly normal renal function, with $24-\mathrm{h} \mathrm{CrCl}$ of $84.0 \pm 3.1 \mathrm{~cm}^{3} / \mathrm{min} /$ $1.73 \mathrm{~m}^{2}$ (range $48-141 \mathrm{~cm}^{3} / \mathrm{min} / 1.73 \mathrm{~m}^{2}$ ). As expected with cisplatin-based therapy, renal function declined progressively with each cisplatin course. Linear regression of $24-\mathrm{h} \mathrm{CrCl}$ values with course number demonstrated a decline in $\mathrm{CrCl}$ at a rate of $3.7 \mathrm{~cm}^{3} / \mathrm{min}$ per course $(n=404, r=0.46, p<0.001)$.
Serum magnesium values declined at a rate of $0.03 \mathrm{meq} / \mathrm{liter}$ per course $(n=404, r=0.33, P<0.001)$, reflective of renal tubular magnesium wasting resulting from cisplatin-induced renal tubular damage (Table II) $(16,17)$. The decline in renal tubular function measured by serum magnesium values, however, underestimates the true rate of fall of serum magnesium and the continued cisplatin-induced tubular damage because of aggressive magnesium supplementation given to keep serum magnesium values above $1.0 \mathrm{meq} /$ liter. Like the pattern of hemoglobin decline, renal dysfunction was detectable even after the first course of therapy and progressed with each course.

\section{Predictors of therapy-induced anemia}

Cisplatin-induced renal dysfunction. The degree of therapy-induced anemia correlated with the amount of cisplatin-induced renal damage. This relationship was reflected by a correlation of hematocrit and 24-h $\mathrm{CrCl}(n=250, r=0.35, P=0.004)$. Red cell mass measurements in a subset of patients also correlated with $24-\mathrm{h} \mathrm{CrCl}$. Hematocrit correlated more strongly with a measure more relevant to renal tubular function, the serum magnesium level ( $P=245, r=0.44, P<0.001$ ) (Fig. 2). There was a significant inverse correlation between the amount of renal damage $(\mathrm{CrCl})$ and the number of cumulative red cell transfusions $(n=404, r=0.49, P<0.001$ ) (data not shown). Patients receiving $>3$ total $U$ of red cells had lower final 24$\mathrm{h} \mathrm{CrCl}$ than those receiving $<3 \mathrm{U}(P=0.025)$. The proportion of patients requiring magnesium supplementation was higher in patients receiving $>5 \mathrm{U}(P=0.072)$ and $>7 \mathrm{U}(P=0.028)$ of red cells than those receiving fewer transfusions.

The degree of EPO response to therapy-induced anemia correlated with the amount of cisplatin-induced renal damage. This relationship was reflected by a correlation between the $\mathrm{O} /$

Table II. Measures of Renal Dysfunction in Patients before Each Course of Cisplatin/Doxorubicin Chemotherapy

\begin{tabular}{lccccccccccc}
\hline & \multicolumn{10}{c}{ Chemotherapy course } \\
\cline { 2 - 12 } & 1 & 2 & 3 & 4 & 5 & 6 & 7 & 8 & 9 & 10 \\
\hline Magnesium (meq/liter) & 1.73 & 1.57 & 1.45 & 1.34 & 1.37 & 1.42 & 1.33 & 1.31 & 1.38 & 1.44 \\
& $(0.03)$ & $(0.02)$ & $(0.03)$ & $(0.03)$ & $(0.04)$ & $(0.05)$ & $(0.03)$ & $(0.04)$ & $(0.05)$ & $(0.06)$ \\
$\mathrm{CrCl}\left(\mathrm{cm}^{3} / \mathrm{min} / 1.73 \mathrm{~m}^{2}\right)$ & 83.9 & 76.9 & 71.4 & 68.8 & 64.9 & 59.1 & 61.7 & 54.3 & 53.1 & 49.1 \\
& $(3.1)$ & $(3.7)$ & $(2.9)$ & $(2.8)$ & $(2.6)$ & $(2.2)$ & $(2.9)$ & $(3.0)$ & $(3.4)$ & $(3.0)$ \\
O/E EPO* & 80.1 & 65.2 & 60.8 & 60.9 & 53.2 & 66.6 & 54.4 & 57.4 & 62.7 & 58.3 \\
& $(5.1)$ & $(4.1)$ & $(3.0)$ & $(3.2)$ & $(3.2)$ & $(5.0)$ & $(4.7)$ & $(14.0)$ & $(4.6)$ & $(7.8)$
\end{tabular}

Values are given as mean (SE). ${ }^{*}$ O/E EPO is the ratio of observed/expected serum EPO levels $\times 100$ and is tabulated here only from values up until the first red cell transfusion. 

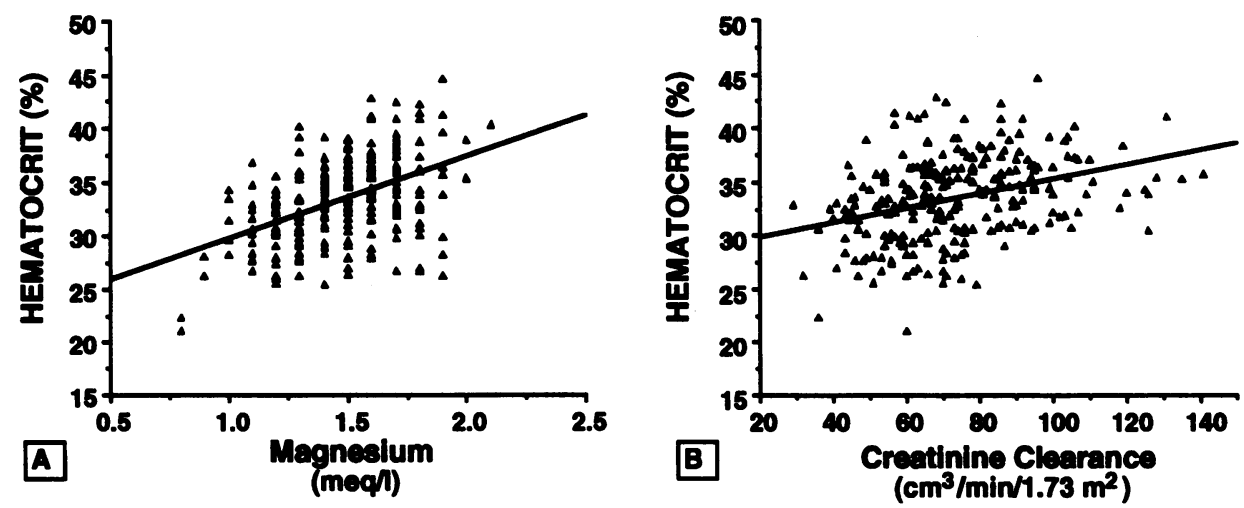

Figure 2. Correlation of the fall in patient hematocrit with renal dysfunction, as measured by the fall in serum magnesium $(A)$ and 24-h $\mathrm{CrCl}(B)$ during cisplatin/doxorubicin chemotherapy.
E EPO values and renal damage measured by $24-\mathrm{h} \mathrm{CrCl}(n=$ $188, r=0.15, P<0.02$ ) and more strongly by serum magnesium levels ( $n=186, r=0.39, P<0.01$ ) (Fig. 3).

Cisplatin vs non-cisplatin renal dysfunction. Patients were stratified by degree of renal dysfunction using $24-\mathrm{h} \mathrm{CrCl}$ into normal renal funetion $\left(90-140 \mathrm{~cm}^{3} / \mathrm{min} / 1.73 \mathrm{~m}^{2}\right.$ ), mild dysfunction $\left(70-90 \mathrm{~cm}^{3} / \mathrm{min} / 1.73 \mathrm{~m}^{2}\right)$, and moderate dysfunction $\left(45-70 \mathrm{~cm}^{3} / \mathrm{min} / 1.73 \mathrm{~m}^{2}\right)$ and into cisplatin treated (more than four courses of treatment) and non-cisplatin treated (before any treatment). The calculated $\mathrm{O} / \mathrm{E}$ EPO values before and after cisplatin-based chemotherapy were compared in each category of renal dysfunction. The O/E EPO values did not differ significantly among cisplatin- and non-cisplatin-treated patients in the normal renal function category $(\mathrm{O} / \mathrm{E}$ : cisplatin $65.8 \pm 11.4$, non-cisplatin $75.1 \pm 14.4 \%, P=N S$ ). However, when renal function approached the level of mild dysfunction, the O/E EPO ratio in cisplatin-treated patients approached significantly lower values than that in non-cisplatin-treated patients with a similar degree of renal dysfunction (O/E: cisplatin $64.9 \pm 3.3$, non-cisplatin 78.2 $\pm 7.0 \%, P=0.056$ ). This differential depression in EPO response in cisplatin-induced renal dysfunction compared with non-cisplatin etiologies for a similar degree of renal dysfunction was significant at the moderate renal dysfunction level (O/E: cisplatin $54.2 \pm 2.6$, non-cisplatin $82.0 \pm 9.7 \%, P<0.001)$.

Patient variables. Multiple-way ANOVA were done to evaluate other potentially relevant factors that might contribute to treatment-induced anemia. The parameters examined included the amount of treatment (course 1 vs $2-4$ vs $5-10$ ), initial tumor burden (small vs large), smoking status during treatment (yes vs no), and tumor response (complete vs partial response vs unresponsive). These analyses showed that course number (e.g., the amount of cisplatin administered) was by far the strongest (greatest $F$ value) single predictor of therapyinduced anemia as measured by hemoglobin, cumulative number of red cell transfusions, and O/E EPO values (Table III). Estimated pretreatment tumor burden did not affect the initial hemoglobin concentration, but was associated with a greater need for transfusion during therapy. Initial tumor burden had no impact upon renal function or endogenous EPO response during therapy. Interestingly, the effect of having achieved a complete response was associated with diminished anemia and less need for transfusions. Complete tumor response was also associated with less severe renal dysfunction and a better endogenous EPO response during therapy. A significant effect of smoking status on treatment-induced anemia was found. Smokers had a slightly lower rate of decline in hemoglobin, had EPO levels closer to the expected response for a given hematocrit, and had less renal toxicity than nonsmokers.

Results were also evaluated excluding patients $(n=6)$ who had received treatment before study entry (chemotherapy, radiation therapy, or any therapy). These patients did not differ in their baseline renal function or hemoglobin values before therapy or in their degree of cisplatin-associated anemia, transfusion rates, renal dysfunction, or number of courses completed at the termination of the study when compared with patients without a prior treatment history. Exclusion of these patients did not influence the overall correlation of renal toxicity, anemia, and EPO response.

Behavior of unique doxorubicin toxicities. The contribution of doxorubicin toxicity to this chronic progressive anemia is difficult to assess independently. To attempt to evaluate this contribution, the incidence of treatment-induced anemia in subgroups of patients with other measurable doxorubicin-associated
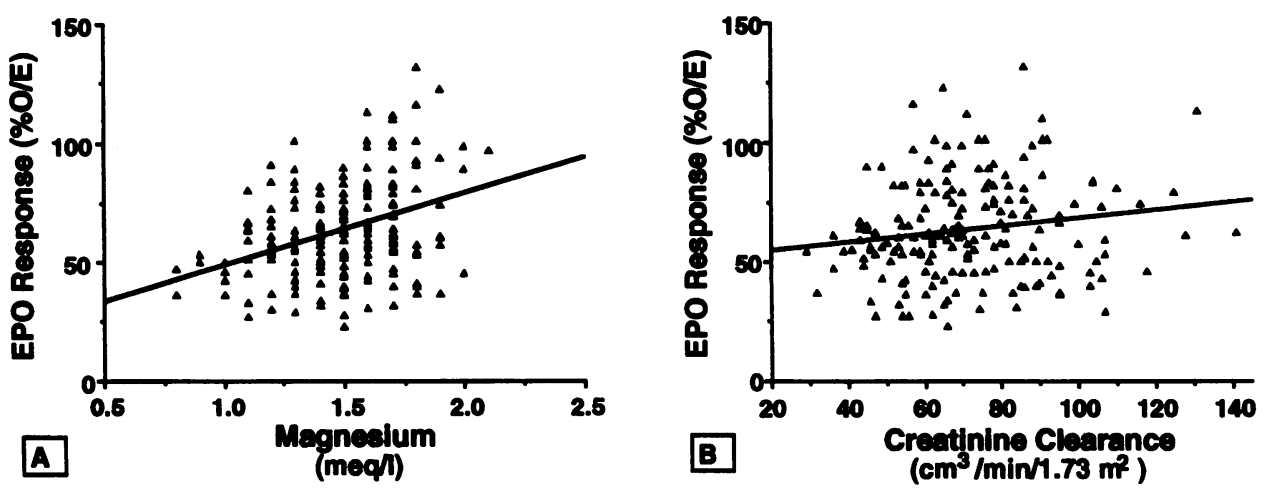

Figure 3. Correlation of the fall in patient EPO response with the fall in serum magnesium $(A)$ and $24-\mathrm{h} \mathrm{CrCl}$ $(B)$ during cisplatin/doxorubicin therapy. The EPO response is the ratio of O/E EPO level $\times 100$, corrected for the concurrent hematocrit. 
Table III. Results of Multivariant Analysis of Patient Variables Affecting Chemotherapy-Induced Toxicities

\begin{tabular}{|c|c|c|c|c|c|c|c|c|}
\hline \multirow[b]{2}{*}{ Patient variables } & \multicolumn{2}{|c|}{ Anemia } & \multicolumn{2}{|c|}{ Transfusions } & \multicolumn{2}{|c|}{ Renal function } & \multicolumn{2}{|c|}{ EPO response } \\
\hline & $\mathbf{F}$ & $\mathbf{P}$ & $\mathbf{F}$ & $\mathbf{P}$ & $\mathrm{F}$ & $\mathbf{P}$ & $\mathbf{F}$ & $\mathbf{P}$ \\
\hline Course & 17.0 & $<0.001$ & 63.7 & $<0.001$ & 51.8 & $<0.001$ & 15.5 & $<0.001$ \\
\hline Tumor response & 5.3 & 0.002 & 15.0 & $<0.001$ & $<1$ & NS & 5.9 & $<0.016$ \\
\hline Tumor burden & 4.1 & 0.045 & 9.4 & $<0.002$ & 16.4 & $<0.001$ & $<1$ & NS \\
\hline Smoking status & $<1.0$ & NS & 2.0 & 0.160 & 12.3 & 0.001 & 19.1 & $<0.001$ \\
\hline
\end{tabular}

Multiple-way ANOVA were performed for each parameter: Anemia, hemoglobin as a percentage of the value at study entry; Transfusions, cumulative units of red cells; Renal function, $24-\mathrm{h} \mathrm{CrCl}$ as a percentage of the value at study entry; EPO response, ratio of observed/expected EPO values. Each toxicity parameter was analyzed for the relative effects of course number, tumor response, initial tumor burden, and smoking status during treatment. $F$ values and $P$ values of each of these analyses are listed. NS, not significant. See text for definition of patient variables.

toxicities was assessed. 11 of 47 patients manifested objective evidence for doxorubicin-induced cardiac dysfunction by significant and progressive decline in nuclear-gated cardiac ejection fractions during chemotherapy. Patients with and without evidence of this doxorubicin-associated cardiac dysfunction did not differ in the number of courses completed or the cumulative doxorubicin or cisplatin doses received. 10 of these 11 patients with doxorubicin-associated cardiotoxicity required red cell transfusions, and 30 of the 36 patients without doxorubicinassociated cardiac dysfunction required transfusions, which was not significantly different (chi-square $=0.71, P=\mathrm{NS}$ ). The average number of transfusions in these two groups did not differ, nor did the severity of cisplatin-induced renal toxicity.

\section{Long-term follow-up of cisplatin-induced toxicities}

10 evaluable long-term survivors from this study were available for assessment of recovery from therapy-induced toxicities. These patients were studied $4.2 \pm 0.8 \mathrm{yr}$ after their last course of cisplatin/doxorubicin and had received $460 \pm 33 \mathrm{mg} / \mathrm{m}^{2}$ cisplatin. After completing therapy, hemoglobin, $\mathrm{CrCl}$, serum magnesium, and serum EPO levels all declined significantly, with half or more patients requiring red cell transfusions and magnesium therapy (Table IV). In long-term follow-up, there was no significant recovery of renal glomerular filtration capacity measured by $24-\mathrm{h} \mathrm{CrCl}$. However, follow-up serum magnesium levels, as a measure of renal tubular function, returned to within the normal range. Although the follow-up magnesium values were significantly lower than pretreatment values, none of these 10 patients required magnesium supplementation to maintain these levels. Hemoglobin and EPO values were higher at followup than posttreatment values and actually exceed pre-cisplatin values when EPO values are assessed relative to the corresponding hematocrit. This indicates that with complete cancer control the ability to produce both red blood cells and EPO normally can be recovered in spite of permanent, moderate renal damage, reversing both the cancer-induced anemia of chronic disease and the cisplatin-associated anemia.

\section{Rat studies}

Cisplatin-induced renal toxicity. During administration of eight doses of cisplatin over $25 \mathrm{~d}$ (total $16 \mathrm{mg} / \mathrm{kg}$ ), normal rats developed a progressive decline in renal function measured by a three- to fourfold rise in serum creatinine (Fig. 4). Several days after stopping cisplatin treatment, renal dysfunction reached a plateau and remained abnormal over the next $25 \mathrm{~d}$ of observation.

Table IV. Comparison of Renal Toxicities and Anemia before and during Chemotherapy and in Long-Term Follow-up in 10 Cured Cancer Patients

\begin{tabular}{|c|c|c|c|c|c|}
\hline & \multicolumn{5}{|c|}{ Chemotherapy Course } \\
\hline & Study entry & $\begin{array}{l}\text { Completion } \\
\text { of therapy }\end{array}$ & $P$ value* & $\begin{array}{l}\text { Long-Term } \\
\text { follow-up }\end{array}$ & $P$ value $^{\ddagger}$ \\
\hline \multicolumn{6}{|l|}{ Renal function } \\
\hline $\mathrm{CrCl}\left(\mathrm{cm} / \mathrm{min} / 1.73 \mathrm{~m}^{2}\right)$ & $82.1 \pm 3.6$ & $46.8 \pm 5.9$ & $<0.0010$ & $41.7 \pm 3.7$ & NS \\
\hline Serum Mg (meq/liter) & $1.8 \pm 0.1$ & $1.4 \pm 0.1^{\dagger}$ & $<0.0001$ & $1.4 \pm 0.1$ & NS \\
\hline No. patients $\mathrm{Mg}$ supplemented & $0 / 10$ & $5 / 10$ & $<0.0001$ & $0 / 10$ & $<0.001$ \\
\hline \multicolumn{6}{|l|}{ Erythropoietic parameters } \\
\hline Hemoglobin (g/dl) & $12.6 \pm 0.3$ & $10.5 \pm 0.5$ & 0.002 & $13.9 \pm 0.3$ & $<0.0001$ \\
\hline No. patients transfused & $0 / 10$ & $7 / 10$ & $<0.001$ & $0 / 10$ & $<0.001$ \\
\hline $\mathrm{EPO}(\mathrm{mU} / \mathrm{ml})$ & $52.2 \pm 11.2$ & $30.8 \pm 5.4$ & $<0.0001$ & $51.4 \pm 9.2$ & 0.081 \\
\hline
\end{tabular}

10 patients received monthly cisplatin and doxorubicin (total cisplatin dose $460 \pm 33 \mathrm{mg} / \mathrm{m}^{2}$ ). Patients were studied in follow-up at $4.2 \pm 0.8 \mathrm{yr}$ after their last treatment. EPO values were done by enzyme immunoassay, with a normal range of $22-54 \mathrm{mU} / \mathrm{ml}$. Normal serum magnesium $(M g)$ values were 1.4-1.9 meq/liter. $P$ values are from Student's $t$ tests for continuous variables comparing pretherapy with completion of therapy values $(*)$ and completion of therapy with long-term follow-up values $\left(^{\ddagger}\right) . P$ values from chi-square analysis are shown for the number of patients requiring magnesium supplementation and the number of patients transfused with red cells. ${ }^{\dagger}$ These values reflect both cisplatin-induced magnesium wasting and concurrent oral magnesium replacement. NS, not significant. 

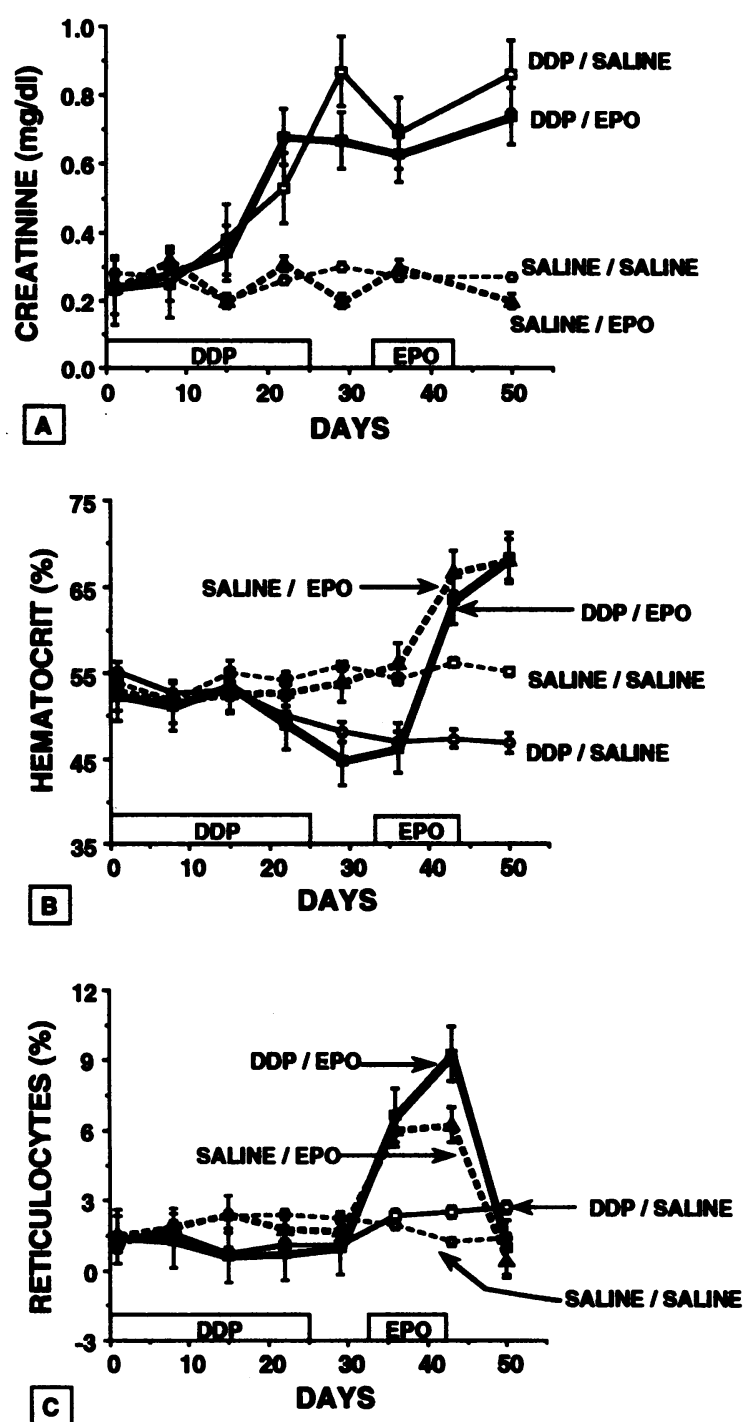

Figure 4. Creatinine $(A)$, hematocrit $(B)$, and reticulocyte $(C)$ values in rats treated with cisplatin $(D D P)$ or saline, followed by recombinant human EPO or saline treatment in study II. Intervals on the $\mathrm{x}$-axis at which drugs were administered are marked. Lines are labeled with the drug treatments for each group of rats. Values are the mean \pm SE.

Cisplatin-induced hematologic toxicity. A progressive anemia accompanied this cisplatin-induced renal damage. Hematocrits gradually fell during cisplatin administration and reached a nadir shortly after the last dose (Fig. 4). The difference in peripheral hematocrit points between saline- and cisplatintreated rats was $12 \%$ in study I (data not shown) and $8.3 \%$ in study II $(54.9 \pm 1.0 \%$ vs $46.6 \pm 1.1 \%, P<0.001)$. The hematocrits remained depressed over the next $25 \mathrm{~d}$ of observation. There was a significant inverse correlation of the hematocrit and serum creatinine in cisplatin-treated rats $(n=48$, $P<0.01$ )

The reticulocyte response varied between saline- and cisplatin-treated rats (Fig. 4). Saline-treated rats showed a slight rise in blood reticulocyte concentrations over pretreatment values, reflecting the effects of weekly blood sampling, whereas the hematocrit remained unchanged. Cisplatin-treated rats failed to increase their blood reticulocytes both during and following cisplatin administration, despite progressive anemia. Reticulo-
Table V. Serum EPO, Hematocrit, and Reticulocyte Response in Cisplatin-, Saline-, and APH-Treated Rats

\begin{tabular}{lcccc}
\hline & & \multicolumn{3}{c}{ After } \\
\cline { 3 - 5 } & Before & Saline & Cisplatin & APH \\
\hline EPO (mU/ml) & $102 \pm 35$ & $170 \pm 65$ & $200 \pm 60$ & $377 \pm 129$ \\
Hematocrit (\%) & $51.0 \pm 2.3$ & $53.3 \pm 0.4$ & $48.4 \pm 0.8$ & $44.8 \pm 0.9$ \\
Reticulocytes (\%) & $1.6 \pm 0.2$ & $1.7 \pm 0.2$ & $0.8 \pm 0.1$ & $6.1 \pm 0.5$ \\
No. of samples & 23 & 15 & 18 & 6 \\
\hline
\end{tabular}

Serum EPO values by enzyme immunoassay did not differ between saline- and cisplatin-treated rats when measured during the last week of treatment and $3 \mathrm{~d}$ following completion of treatment. APH was administered to another group of rats to induce an anemia with an elevated reticulocyte and EPO response for comparison with saline- and cisplatin-treated rats $(P<0.001)$.

cyte values fell below those of saline-treated rats and pretreatment values. At the completion of drug treatment, reticulocytes were $0.8 \pm 0.2 \%$ in cisplatin-treated rats and $1.7 \pm 0.2 \%$ in salinetreated rats $(P=0.005) .25 \mathrm{~d}$ after cessation of cisplatin administration, reticulocyte values in cisplatin-treated rats were moderately increased over values in saline-treated rats $(2.4 \pm 0.4$ vs $1.5 \pm 0.3 \%, P=0.059)$. This moderate reticulocyte response was inadequate, since the hematocrit of cisplatin-treated rats remained depressed. Depression of hematocrit, long after the cessation of cisplatin, was observed for up to $49 \mathrm{~d}$ in study I and $25 \mathrm{~d}$ in study II. At the termination of study II, rats not given exogenous EPO, measurement of central blood values confirmed the cisplatin-induced anemia, with reduced central hematocrits (cisplatin $27.9 \pm 1.0$ vs saline $34.5 \pm 1.1 \%, P$ $<0.001)$, red cell numbers $\left(5.28 \pm 0.18\right.$ vs $6.11 \pm 0.18 \times 10^{12} /$ liter, $P=0.006)$, and hemoglobin values $(13.0 \pm 0.3 \mathrm{vs}$ $14.8 \pm 0.2 \mathrm{~g} / \mathrm{dl}, P<0.001)$, with a slight increase in mean red cell volume $(58.3 \pm 0.4$ vs $56.0 \pm 0.3 \mathrm{fl}, P<0.001)$ compared with saline-treated rats. In contrast there was no difference in white blood cell counts $\left(7.2 \pm 0.6\right.$ vs $8.8 \pm 0.7 \times 10^{9} /$ liter, $P$ $=\mathrm{NS}$ ) or in white cell differential counts (data not shown) between cisplatin- and saline-treated rats at this time.

Endogenous EPO response. EPO levels in rats before any treatment (day 1) and at the end of saline or cisplatin treatment (days 22-29) were compared in study II. Plasma EPO levels of cisplatin-treated rats did not differ from those of salinetreated rats or rats evaluated before treatment (Table V) despite the fall in hematocrit in cisplatin-treated rats. This is in contrast to the significant elevation of plasma EPO levels seen in rats rendered anemic by APH, which causes a depression in hematocrit with an appropriately elevated reticulocyte response.

Response to exogenous human recombinant EPO. In study II, administration of subcutaneous recombinant human EPO twice weekly, $6 \mathrm{~d}$ after cessation of cisplatin, rapidly increased the hematocrit and blood reticulocytes (Fig. 4) in cisplatin- and saline-treated rats. The final EPO-induced increment in hematocrit was significantly greater in cisplatin-treated rats given EPO than in non-cisplatin-treated rats given EPO $(21.8 \pm 1.1$ vs $13.6 \pm 0.8$ points, $P<0.001)$. The EPO-induce increment in blood reticulocytes was also greater in cisplatin-treated rats given EPO $(P<0.05)$ than in non-cisplatin-treated rats given EPO. EPO treatment did not alter serum creatinine values in cisplatin- or saline-treated rats (Fig. 4). In study I, subcutaneous EPO was initiated $32 \mathrm{~d}$ after completing cisplatin treatments. 
Greater hematocrit increments were also seen in previously cisplatin-treated rats than non-cisplatin-treated rats ( 22 vs $15-$ point increment, $P<0.001$ ) (data not shown). These results indicate that the marrow of repeatedly cisplatin-treated mammals can respond vigorously to appropriate EPO concentrations.

\section{Discussion}

Cancer patients constitute a heterogeneous group with respect to disease biology. The anemia of malignancy is multifaceted. Inhibitory effects of tumor/host cytokines on EPO production (18) and erythroid precursor cell responsiveness $(19,20)$, abnormalities in iron reutilization, and decreased red cell survival have been documented. Nutritional deficiencies, inhibitory effects of infectious and surgical events, and tumor-induced blood loss can contribute to anemia. Direct marrow suppression by chemotherapy, radiation therapy, marrow fibrosis, or tumor invasion may also contribute to anemia (21). Drug-induced renal dysfunction, which results in EPO deficiency, may contribute to anemic states in some cancer patients. Examples of such renal toxins administered to cancer patients include cisplatin $(16,17,22)$ and amphotericin B (23), both of which are dose limited by nephrotoxicity and cause primarily renal tubular dysfunction.

In a homogeneous group of carefully studied cancer patients receiving cisplatin/doxorubicin therapy and in rats receiving cisplatin, we have found a significant hypoproliferative anemia. No cases of the rare form of cisplatin hemolytic anemia were detected (24). The anemia occurs early, is cumulative, is disproportionate to white blood cell changes, and necessitates red cell transfusion in the vast majority of successfully treated cancer patients. Bone marrow cellularity was slightly depressed; however, myeloid/erythroid ratios were preserved. A hypoproliferative anemia could result from drug-induced EPO deficiency and/or direct drug-induced suppression of marrow precursors. We present evidence that cisplatin-associated anemia in cancer patients and in normal rats is associated with inhibition of the endogenous EPO response, which in both cases correlates with cisplatin-induced renal damage. The cisplatin-induced anemia in the rat can be rapidly obviated by EPO. Others have demonstrated that anemia in cancer patients receiving cisplatin-containing chemotherapy can be effectively alleviated by EPO (25-28).

Cisplatin has not been associated clinically with significant multilineage marrow toxicity at moderate doses. This granulopoietic sparing effect of cisplatin accounts for much of its success when combined with full doses of myelotoxic drugs. The myelotoxicity of single-agent cisplatin has been manifested by mild leukopenia in a minority of heavily pretreated patients (12, 29 ) or in similar proportions of better performance patients given cisplatin at higher doses (30). These white cell changes have been transient and not cumulative, unlike the anemia. Cisplatin administration in animals has caused either no myelotoxicity or transient changes in white blood cell numbers and marrow progenitor numbers at high doses $(9,31,32)$. We found that repeated, moderate dose cisplatin administration in rats caused anemia with no persistent effects on white blood cell counts.

The anemia in these cisplatin-treated rats with mild azotemia responded vigorously to EPO administration, generating an erythropoietic response greater than that in non-cisplatin-treated rats given EPO. Matsumoto et al. studied the response of rats to EPO and found it more effective in correcting the anemia induced by cisplatin than the anemia induced by 5 -fluorouracil (8). This is interesting in light of our observations in rats of the apparent dissociation of cisplatin-induced anemia and renal dysfunction from marrow damage. In contrast, 5-fluorouracil causes anemia with elevated EPO levels and direct toxicity to the bone marrow progenitors. Collectively, these findings further support the idea that the anemia associated with repeated cisplatin administration is largely a hormone deficiency (EPO) secondary to damage to renal tubular and/or peritubular tissues that sense hypoxia and/or produce EPO. Most clinical EPO trials in patients receiving cisplatin have not reported serial measures of renal function or cumulative cisplatin doses and have excluded patients when their renal function declined. Therefore, it is not known whether cisplatin-induced anemia in patients with significant drug-induced renal dysfunction responds better to EPO than anemia in chemotherapy patients without cisplatin nephropathy, as it does in rats.

EPO deficiency with cisplatin therapy has been suggested in previous studies to contribute to anemia $(10,12,33)$. The EPO response (percentage of expected EPO level for the hematocrit) in our patients decreased with each course and correlated with the 24-h $\mathrm{CrCl}$ and serum magnesium. Plasma EPO concentrations in rats treated with several doses of cisplatin also failed to increase in the face of progressive anemia and moderate renal dysfunction. These results are consistent with the lack of an EPO response seen in rats treated with single-dose cisplatin and correction with EPO administration reported by Matsumoto et al. (8). Whether the reduction in the EPO response is the result solely of renal dysfunction or whether, in addition, the deficiency in magnesium itself may impair EPO production or release is not known but could be tested in further studies.

Cisplatin chemotherapy in smaller patient series has been reported to cause a delayed, progressive anemia, disproportionate to white cell changes, in over half of patients that then require transfusions $(11,34,35)$. The development of anemia in our patients, however, was not delayed, but was seen immediately after the first course of therapy and progressed with further treatment. An explanation other than just decreased red cell production from EPO deficiency seems necessary to explain these observations, given a normal red cell life span of $120 \mathrm{~d}$. Other contributing factors to this earlier than expected anemia onset might be the diminished red cell half-life seen in the anemia of chronic disease, which has been, in part, attributed to factors outside the red cell based on cross-transfusion studies (36). In a subset of our patients undergoing cisplatin-based chemotherapy, we demonstrated a $40 \%$ decrease in the red cell half-life compared with the values in normal volunteers. EPO itself has an apparent affect on red cell half-life, since disorders associated with a deficiency in EPO have a decrease in red cell half-life, and the administration of recombinant EPO in these disorders increases the red cell half-life $(37,38)$. EPO can prolong the survival of CFU-E precursors and proerythroblasts by preventing cell apoptosis (39), but how this translates to prolonged mature erythrocyte life span is not clear. In our cisplatin-treated cancer patients, shortened red cell half-life due to the malignant process and to the progressive deficiency in EPO and decreased production of red cells from EPO deficiency could all contribute to an early fall in hemoglobin. Doxorubicin given concurrently to these cancer patients would also transiently inhibit red cell production through direct marrow toxicity. Additional direct effects of these drugs on red cell survival through subtle oxidative effects are possible but were not measured. Immune-mediated destruction of red cells reflected by the 
absence of direct Coomb's positively was not found. Cisplatin in animal models causes an anemia with a delayed appearance of about 2 wk after single $(8,9)$ or repeated doses $(10)$. Cisplatin anemia in our rats was also delayed and cumulative, and it persisted for more than 4-7 wk after treatment. The model of the cisplatin-treated rat differs from these patients in that rats did not have tumors and doxorubicin was not administered. These differences could alter the rate of fall of hemoglobin by the lack of a tumor effect on red cell half-life and the lack of a marrow effect from doxorubicin. The recognition of an earlier onset of anemia with cisplatin chemotherapy in patients may warrant the earlier intervention with prophylactic administration of EPO to prevent this anemia. The majority of EPO trials in chemotherapy patients receiving cisplatin $(25-28)$ or noncisplatin $(40,41)$ chemotherapy have initiated EPO therapy after the appearance of anemia, with improved hematocrits and decreased transfusion rates.

Anemia in our cancer patients was highly associated with the progressive development of cisplatin-induced renal dysfunction, as indicated by $24-\mathrm{h} \mathrm{CrCl}$, but was more strongly correlated with renal tubular damage (fall in serum magnesium). Our transfusion rates correlated with cisplatin-induced renal damage. Rates of red cell transfusions have been reported to be higher in cisplatin- than non-cisplatin-containing chemotherapy (35). Other studies, however, have failed to find a correlation between cisplatin-induced anemia and renal function (33, 42). Many of these studies have reported small patient numbers, heterogeneous tumor types, variable chemotherapy regimens, and lower cumulative cisplatin doses. Many cisplatin studies have not followed renal function serially and have not thoroughly characterized anemia before and during chemotherapy. Serum creatinine concentrations have often been used to measure cisplatin-induced renal damage; such measurements poorly reflect kidney damage that is primarily tubular. We have tried to overcome many of these shortcomings in our study. The strongest correlation we found was between the decrement in serum magnesium concentrations and anemia during therapy. This was further supported by the correlation of restoration of serum magnesium levels with the correction of anemia and EPO response in long-term follow-up of patients in the absence of restoration of $\mathrm{CrCl}$ values. Cisplatin-associated anemia and blunted EPO response occur at a level of renal glomerular dysfunction, measured by $24-\mathrm{h} \mathrm{CrCl}$, far less severe than that associated with other causes of renal dysfunction. This also indicates that cisplatin may well cause a relatively more specific or targeted non-glomerular cell damage. Amphotericin B is an example of another renal tubular poison that is associated with renal magnesium wasting, anemia, and an inappropriately low EPO response that only gradually resolve after stopping the drug (43). It can be argued that an even better measure of renal tubular or peritubular cell function than serum magnesium could be a more useful anemia predictor with these types of drugs.

The exact mechanism by which cisplatin-induced renal damage prevents an EPO response to anemia is not known. Cisplatin could conceivably inhibit renal sensing of anemia and/or renal production of EPO. Cisplatin can react with nucleophilic sites in not only DNA, but also RNA and protein. Cisplatin forms complexes with cellular glutathione, which then can directly inhibit protein synthesis (44). Cisplatin is eliminated by renal excretion and is more highly concentrated in renal tissue, where it demonstrates very prolonged (weeks) tissue retention, than in any other tissue type $(45,46)$. Increased tissue deposition of platinum also occurs with repeated administration of cisplatin
(47). Though cisplatin clearly damages renal tubular epithelial cells, as shown by histologic changes and markers of renal tubular cell function, changes in renal interstitial tissues also occur, including edema and fibrosis $(12,16)$. Cisplatin-induced alterations in renal tubular function (renal tubular magnesium wasting) appear to be slowly reversible; however, changes in $\mathrm{CrCl}$ appear to be fixed, as reported here and elsewhere (16, 17). Therefore, accumulation of cisplatin and/or redistribution of other metals by cisplatin (48) within the tubular or peritubular spaces of the kidney might lead to inhibition of the sensing mechanism for tissue hypoxia or inhibition of EPO production. The slow excretion of cisplatin from the kidney and increased retention after previous dosing would be consistent with delayed restoration of renal tubular function and delayed normalization of hematocrit and EPO levels.

The finding of protection from cisplatin-induced renal dysfunction and EPO deficiency in patients who smoked was unexpected. The mechanism for this is unknown, but several lines of thought are worth considering. The metabolism of many drugs is altered in smokers (49), usually through altered hepatic metabolism; however, cisplatin does not undergo hepatic metabolism. Differences in cisplatin distribution have not been compared in smokers and nonsmokers. Thiol compounds can modulate cisplatin toxicity and serum thiocyanate levels are elevated in smokers. Whether thiocyanate can modulate cisplatin toxicity is not known. Elevated levels of heavy metals such as cadmium are found in cigarette smoke and the blood and renal tissue of smokers $(50,51)$. Cadmium is known to induce metallothionein synthesis. Metallothionein has been implicated in the sequestration of platinum and other metals and can prevent the lethal and renal toxicity caused by cisplatin administered to animals (52). It is not known whether metallothionein is elevated in smokers compared with nonsmokers or whether this might alter cisplatin renal toxicity in smokers. Studies along these lines would be of interest.

The lower renal toxicity and better EPO response seen in our cancer patients with complete remission of their tumor after chemotherapy was another unexplained finding. It is interesting that in vivo cisplatin resistance of tumors in animals has been associated with in vivo redistribution of the drug, with lower levels in the resistant tumor and higher levels in normal tissues (53), which might explain this proactive inverse relation of host and tumor toxicity. In any event, these results in both humans and rats add to the case for the likelihood that cisplatininduced anemia is at least in part an iatrogenic endocrine deficiency syndrome.

\section{Acknowledgments}

This work was supported in part by a University of Minnesota General Clinical Research Center grant (5M-01RR00400; to W.J.M.H.); by National Institutes of Health grant (R01 CA-31635; to W.J.M. Hrushesky), and by VA Merit and Research Advisory Group grants (to W.J.M. Hrushesky and P.A. Wood).

\section{References}

1. Koury, S. T., M. C. Bondurant, and M. J. Koury. 1988. Localization of erythropoietin synthesizing cells in murine kidneys by in situ hybridization. Blood. 71:524-527.

2. Lacombe, C., J. L. Silva, P. Bruneval, J. G. Fournier, F. Wendling, C. Casadevall, J. P. Camilleri, J. Bariety, B. Varet, and P. Tambourin. 1988. Peritubular cells are the site of erythropoietin synthesis in the murine hypoxic kidney. $J$. Clin. Invest. 81:620-623.

3. Loya, F., Y. Yang, H. Lin, E. Goldwasser, and M. Albitar. 1994. Transgenic 
mice carrying the erythropoietin gene promoter linked to lac $\mathrm{Z}$ express the reporter in proximal convoluted tubule cells after hypoxia. Blood. 84:1831-1836.

4. Adamson, J. W., J. W. Eschbach, and C. A. Finch 1968. The kidney and erythropoiesis. Am. J. Med. 44:725-733.

5. Neilson, O. V., and J. H. Thaysen. 1989. Erythropoietin deficiency in acute renal failure. Lancet i:624.

6. Lim, V. S., R. L. DeGowin, and D. Zavala. 1989. Recombinant human erythropoietin treatment in predialysis patients. Ann. Intern. Med. 110:108-114.

7. Winerals, C. G., D. O. Oliver, M. J. Pippard, C. Reid, M. R. Dowing, and P. M. Cotes. 1986. Effect of human erythropoietin derived from recombinant DNA on the anemia of patients maintained by chronic hemodialysis. Lancet. ii:1175-1178.

8. Matsumoto, T., K. Endoh, K. Kamisango, K. I. Akamatsu, K. Koizumi, M. Higuchi, N. Imai, H. Mitsui, and T. Kawagueti. 1990. Effect of recombinan human erythropoietin on anticancer drug-induced anemia. Br. J. Haematol. 75:463-468

9. Nowrousian, M. R., and C. G. Schmidt. 1982. Effects of cisplatin on different haemopoietic progenitor cells in mice. Br. J. Cancer. 46:397-402

10. Wood, P. A., and W. J. M. Hrushesky. 1984. Cisplatin-induced anemia: an erythropoietin deficiency syndrome. Proc. Am. Soc. Clin. Oncol. 3:154a. (Abstr.)

11. Wiltshaw, E., and T. Kroner. 1976. Phase II study of cis-dichlorodiammineplatinum (II) (NSC-119875) in advanced adenocarcinoma of the ovary. Cancer Treat. Rep. 60:55-60.

12. Rossof, A. H., R. E. Slayton, and C. P. Perlia. 1972. Preliminary clinical experience with cis-diamminedichloroplatinum (II) (NSC 119875, CACP). Can cer. 30:1451-1456.

13. Klaussen, D. K., and J. L. Spivak. 1990. Hepatitis-related erythropoietin production. Am. J. Med. 89:684-686.

14. Hrushesky, W. J. M., F. Lévi, F. Halberg, and B. J. Kennedy. 1982. Circadian stage dependence of cis-diamminedichloroplatinum lethal toxicity in rats. Cancer Res. 42:945-949.

15. Hrushesky, W. J. M., R. Borch, and F. Levi. 1982. Circadian time dependence of cisplatin urinary kinetics. Clin. Pharmacol. Ther. 32:330-339.

16. Dentino, M., R. C. Luft, N. M. Yum, D. S. Williams, and L. H. Einhorn 1978. Long term effects of cis-diamminedichloride platinum (CDDP) on rena function and structure in man. Cancer. 41:1274-1281.

17. Fjeldborg, P., J. Sorensen, and P. E. Helkjaer. 1986. The long-term effect of cisplatin on renal function. Cancer. 58:2214-2217.

18. Faquin, W. C., T. J. Schneider, and M. A. Goldberg. 1992. Effect of inflammatory cytokines on hypoxia-induced erythropoietin production. Blood. 79:1987-1994.

19. Means, R. A., and S. B. Krantz. 1991. Inhibition of human erythroid colony-forming units by gamma-interferon can be corrected by recombinant human erythropoietin. Blood. 78:2564-2567.

20. Johnson, R. A., T. A. Waddelow, J. Caro, and G. D. Roodman. 1989 Chronic exposure to tumor necrosis factor in vivo preferentially inhibits erythropoiesis in nude mice. Blood. 74:130-138.

21. Means, R. T., and S. B. Krantz. 1992. Progress in understanding the pathogenesis of the anemia of chronic disease. Blood. 80:1639-1647.

22. Gonzalez-Vitale, J. C., D. M. Hayes, E. Cvitkovic, and S. S. Sternberg 1977. The renal pathology in clinical trials of cis-platinum (II) diamminedichloride. Cancer. 39:1362-1371.

23. Barton, C. H., M. Pahl, N. D. Vaziri, and T. Cesario. 1984. Renal magnesium wasting associated with amphotericin B therapy. Ann. Intern. Med. 77:471474.

24. Getaz, E. P., S. Beckley, J. Fritzpatrick, and A. Dozier. 1980. Cisplatininduce hemolysis. N. Engl. J. Med. 302:334-335.

25. Abels, R. I., K. M. Larholt, K. D. Krantz, and B. C. Bryant. 1991. Recombinant human erythropoietin (r-HuEPO) for the treatment of the anemia of cancer. In Blood Cell Growth Factors: Their Present and Future Use in Hematology and Oncology. M. J. Murphy, editor. Alpha Medical Press, Dayton, OH. $121-141$.

26. Miller, C. B., L. C. Platanias, S. R. Mills, M. L. Zahurak, M. J. Ratin, D. S. Ettinger, and R. J. Jones. 1992. Phase I-II trial of erythropoietin in the treatment of cisplatin-associated anemia. J. Natl. Cancer Inst. 84:98-103.

27. James, R. D., P. M. Wilkinson, F. Belli, R. Welch, and R. Cowan. 1992. Recombinant human erythropoietin in patients with ovarian carcinoma and anemia secondary to cisplatin and carboplatin chemotherapy: preliminary results. Acto Haematol. 87:12-15.

28. Cascinu, S., A. Fedeli, E. Del Ferro, S. L. Fedeli, and G. Catalono. 1994 Recombinant human erythropoietin treatment in cisplatin-associated anemia: a randomized, double-blind trial with placebo. J. Clin. Oncol. 12:1058-1062.

29. Hayes, D. M., E. Cvitkovic, R. B. Golbey, E. Scheiner, L. Helson, and I. Krakoff. 1977. High dose cis-platinum diammine dichloride: amelioration of renal toxicity by mannitol diuresis. Cancer. 39:1372-1381.

30. Gandara, D. R., H. Wold, E. A. Perez, A. B. Diesseroth, J. Doroshow, F Meyers, K. McWhiter, J. Hannigan, and M. W. Degregorio. 1989. Cisplatin dose intensity in non-small cell lung cancer: phase II results of a day 1 and day 8 highdose regimen. J. Natl. Cancer Inst. 81:790-794.

31. Kociba, R. J., and S. D. Sleight. 1971. Acute toxicologic and pathologic effects of cis-diammine dichloroplatinum (NSC-119875) in the male rat. Cancer Chemother. Rep. 555:1-8.

32. Teicher, B. A., S. A. Holden, J. P. Eder, T. W. Brann, S. M. Jones, and E. Frei. 1989. Influence of schedule on alkylating agent cytotoxicity in vitro and in vivo. Cancer Res. 49:5994-5998.

33. Smith, D. H., E. Goldwasser, and E. E. Vokes. 1991. Serum immunoerythropoietin levels in patients with cancer receiving cisplatin-based chemotherapy. Cancer. 68:1101-1105.

34. Kuzar, M. E. 1980. Cisplatin-induced anemia. N. Engl. J. Med. 303:110

35. Henry, D., R. Nelson, B. Brooks, R. Jacobson, S. Jones, A. Keller, J. Kugler, J. Moore, C. Nichols, R. Silver, A. Stoddon, B. Mason, R. Abels, and S. Rudnick. 1991. Prospective evaluation of transfusion (Tx) requirements for anemic cancer patients $+/$ - chemorx. Blood. 78:152a. (Abstr.)

36. Lee, G. R. 1983. The anemia of chronic disease. Semin. Hematol. 20:61-

37. Cotes, M. P., M. J. Pippard, C. D. L. Reid, C. G. Winerals, D. O. Oliver, and J. P. Royston. 1989. Characterization of the anemia of chronic renal failure and the mode of its correction by a preparation of human erythropoietin ( $r$ HuEPO). An investigation of the pharmacokinetics of intravenous erythropoietin and its effects on erythrokinetics. Quart. J. Med. 70:113-137.

38. Hughes, R. T., P. M. Cotes, M. J. Pippard, J. M. Stevens, D. O. Oliver, C. G. Winerals, and J. P. Poyston. 1990. Subcutaneous administration of recombinant human erythropoietin to subjects on continuous ambulatory peritoneal dialysis: an erythrokinetic assessment. Br. J. Haematol. 75:268-273.

39. Koury, M. J., and M. C. Bondurant. 1990. Erythropoietin retards breakdown and prevents death in erythroid progenitor cells. Science (Wash. DC). 248:378-381.

40. Platanias, L. C., C. B. Miller, R. Mick, R. D. Hart, H. Ozer, J. M. McEvilly, R. J. Jones, and M. J. Ratain. 1991. Treatment of chemotherapy-induced anemia with recombinant human erythropoietin in cancer patients. J. Clin. Oncol. 9:2021 2026.

41. Case, D., M. Bukowski, R. W. Carey, E. H. Fishkin, D. H. Henry, R. J. Jacobson, S. E. Jones, A. M. Keler, J. W. Kugler, C. R. Nichols, S. E. Salmon, R. T. Silver, A. M. Storniolo, G. L. Wampler, C. M. Dooley, K. M. Larholt, R. A. Nelson, and R. I. Abels. 1993. Recombinant human erythropoietin therapy for anemic cancer patients on combination chemotherapy. J. Natl. Cancer Inst. 85:801-806.

42. Miller, C. B., R. J. Jones, S. Piantadosi, M. D. Abeloff, and J. L. Spivak. 1990. Decreased erythropoietin response in patients with the anemia of cancer. N. Engl. J. Med. 322:1689-1692.

43. Lin, A. C., E. Goldwasser, E. M. Bernard, and S. W. Chapman. 1990 Amphotericin B blunts erythropoietin response to anemia. J. Infect. Dis. 161:348351 .

44. Ishikawa, T., and F. Ali-Osman. 1993. Glutathione-associated cis-diamminedichloroplatinum (II) metabolism and ATP-dependent efflux from leukemia cells. J. Biol. Chem. 268:20116-20125.

45. Robins, A. B., and M. O. Leach. 1983. Pharmacokinetics of therapeutic doses of isotopically labelled platinum antitumor agents in the mouse and rat. Cancer Treat. Rep. 67:245-252.

46. Leroy, A. F., R. J. Lutz, R. L. Dedrick, C. L. Litterst, and A. M. Guarino. 1979. Pharmacokinetic study of cis-dichlorodiammineplatinum (II) (DDP) in the beagle dog: thermodynamic and kinetic behavior of DDP in a biologic milieu. Cancer Treat. Rep. 63:59-71.

47. Litterst, C. L., and V. G. Schweitzer. 1984. Increased tissue deposition and decreased excretion of platinum following administration of cisplatin to cisplatintreated animals. Cancer Chemother. Pharmacol. 12:46-49.

48. El-Sharkawi, A. M., W. D. Morgan, S. Cobbold, M. B. M. Jaib, C. J. Evans, L. J. Somervaille, D. R. Chettle, and M. C. Scott. 1986. Unexpected mobilization of lead during cisplatin chemotherapy. Lancet. i:249-250.

49. Hart, B., G. C. Farrell, W. G. E. Cooksley, and L. W. Powell. 1976 Enhanced drug metabolism in cigarette smokers. Br. Med. J. 2:147-149.

50. Kjellstrom, T. 1979. Exposure and accumulation of cadmium in populations from Japan, the United States and Sweden. Environ. Health Perspect 28:169-197.

51. Friberg, L., and M. Vahter. 1983. Assessment of exposure to lead and cadmium through biological monitoring. Results of a UNEP/WHO global study. Environ. Res. 30:95-128.

52. Naganumara, A., M. Satoh, and N. Imura. 1987. Prevention of lethal and renal toxicity of cis-diamminedichloroplatinum (II) by induction of metallothionein synthesis without compromising its antitumor activity. Cancer Res. 47:983987.

53. Teicher, B. A., T. S. Herman, S. A. Holden, Y. Wang, M. R. Pfeffer, J. W. Crawford, and E. Frei. 1990. Tumor resistance to alkylating agents conferred by mechanisms operative only in vivo. Science (Wash. DC). 247:1457-1461. 